\title{
THE EFFECT OF LOYALTY CARD ATTITUDE, STORE SATISFACTION AND STORE LOYALTY ON PURCHASE INTENTION: THE CASE OF COSMETICS RETAILERS
}

\author{
DOI: 10.17261/Pressacademia.2019.1069 \\ PAP-V.9-2019(16)-p.74-77
}

\section{Merve Turk ${ }^{1}$, Tutku Eker Iscioglu²}

${ }^{1}$ Piri Reis University, Department of International Business and Trade, Tuzla, Istanbul, Turkey merve.turk@pru.edu.tr, ORCID: 0000-0002-7409-6637

${ }^{2}$ Piri Reis University, Department of International Business and Trade, Tuzla, Istanbul, Turkey teiscioglu@pirireis.edu.tr, ORCID: 0000-0002-4794-6368

To cite this document

Turk, M., Eker Iscioglu, T., (2019). The effect of loyalty card attitude, store satisfaction and store loyalty on purchase intention: the case of cosmetics retailers. PressAcademia Procedia (PAP), V.9, p.74-77

Permemant link to this document: http://doi.org/10.17261/Pressacademia.2019.1069

Copyright: Published by PressAcademia and limited licenced re-use rights only.

\section{ABSTRACT}

Purpose- The purpose of the study is to see if the attitude towards loyalty card programs, store satisfaction and store loyalty create purchase intention in the cosmetics industry. More specifically, two cosmetics retailers -Gratis and Sephora - which are supposed to apply different loyalty programs are selected to examine if there are differences regarding consumers' purchase intention for the two.

Methodology- This research applies PLS-SEM to test the proposed model with the data obtained from 200 respondents who use loyalty cards of Sephora or Gratis.

Findings- The results of Multi Group Analysis reveal that loyalty card attitude and store loyalty create purchase intention for the consumers of Gratis, but not for Sephora. On the other hand, loyalty card attitude exerts more influence on the store satisfaction and loyalty for Sephora than does for Gratis.

Conclusion- Cosmetics retailers should design loyalty programs depending on the expected returns.

Keywords: Loyalty card attitude, store satisfaction, store loyalty, purchase intention, cosmetics retailers JEL Codes: M30, M31, M39

\section{INTRODUCTION}

The idea of engaging companies with their consumers is not new. Especially since 1980s companies have been applying relational marketing tools to create consumer loyalty and thus increase purchase intention. Loyalty programs aim to keep companies from focusing on existing consumers. This is in contrast to the strategies that focus on new consumer acquisition. Unlike other marketing strategies, loyalty programs focus on increasing the average intake and repetitive purchases.

Loyalty programs have been an important aspect of marketing strategies especially for retailers in the cosmetics industry. However, to the knowledge of the authors, no research has been undertaken to understand the effect of loyalty programs on loyalty and purchase intention of cosmetics retailers. This study is an endeavor to fill this gap. More specifically, the study aims to examine which type of loyalty card programs is more likely to create store satisfaction, store loyalty and thus purchase intention. To this end, two cosmetics retailers applying different loyalty card programs are selected. With the data collected from 200 consumers of these retailers, suggested hypotheses are tested with PLS-SEM as a Multi Group Analysis. Theoretical and managerial implications are suggested on account of the findings.

\section{LITERATURE REVIEW AND THE HYPOTHESES}

Loyalty programs can be defined as a supplier's structural effort to increase customers' attitudinal and behavioural commitment to the supplier's market offering (Sharp \& Sharp, 1997). The main objectives of these programs are, to obtain information about existing customers, offer incentives accordingly to retain them and thus increase their shopping frequencies and amounts (Zilliani \& Bellinii 2004).

Studies examining the effects of loyalty card programs and their tools are scarce and they show mixed results (Noordhoff, Pauwels \& Schröder, 2004). Differing studies revealed that loyalty card programs have an impact on store satisfaction, store loyalty and purchase intention. For instance, in the study of Bridson, Evans \& Hickman (2008) loyalty programs were found to be significant predictors of the store satisfaction. Noordhoff et. al. (2004) found that there is a relationship between loyalty card possession and store loyalty although there could 
be cultural differences. Demoulin and Zidda (2008) also confirm that loyalty card owners are more store loyal. Regarding the effect of loyalty card programs on purchase intention, studies again provide evidence to support the relationship. For example, Taylor and Neslin (2005) reveal that loyalty programs contribute to profit. Liu (2007) also found that the loyalty program had positive influence on purchase frequencies and transaction sizes. Likewise, Leenheer et al. (2007) found a small positive effect of loyalty program membership on share of wallet.

Satisfaction has been mostly recognized as an antecedent to loyalty (Homburg and Giering, 2001). Studying the effect of loyalty card programs, Bridson et. al. (2008) indicated that store satisfaction was positively related to store loyalty, more to that it mediates the relationship between loyalty program and store loyalty. On the other hand, although one would expect store satisfaction to result in purchase intention, Macintosh \& Lockshin (1997) found no significant impact of store satisfaction on purchase intention.

It is widely acknowledged that loyalty has a behavioral dimension. The behavioral aspect of loyalty focuses on the proportion of purchase of a specific brand (Caruana, 2002). In the case of store loyalty then, it could be expected that loyalty can lead to purchase intention. In fact, it is at the heart of measuring store loyalty with purchase intention (Cronin and Taylor, 1992).

Considering previous studies in the extant literature, following hypotheses are developed and the research model is displayed in Figure 1.

$H_{1}$ : Loyalty card attitude will positively affect store satisfaction of the consumers of a) Gratis, b) Sephora

$\mathrm{H}_{2}$ : Loyalty card attitude will positively affect store loyalty of the consumers of a) Gratis, b) Sephora

$H_{3}$ : Loyalty card attitude will positively affect purchase intention of the consumers of a) Gratis, b) Sephora

$\mathrm{H}_{4}$ : Store satisfaction will positively affect store loyalty of the consumers of a) Gratis, b) Sephora

$H_{5}$ : Store satisfaction will positively affect purchase intention of the consumers of a) Gratis, b) Sephora

$H_{6}$ : Store loyalty will positively affect purchase intention of the consumers of a) Gratis, b) Sephora

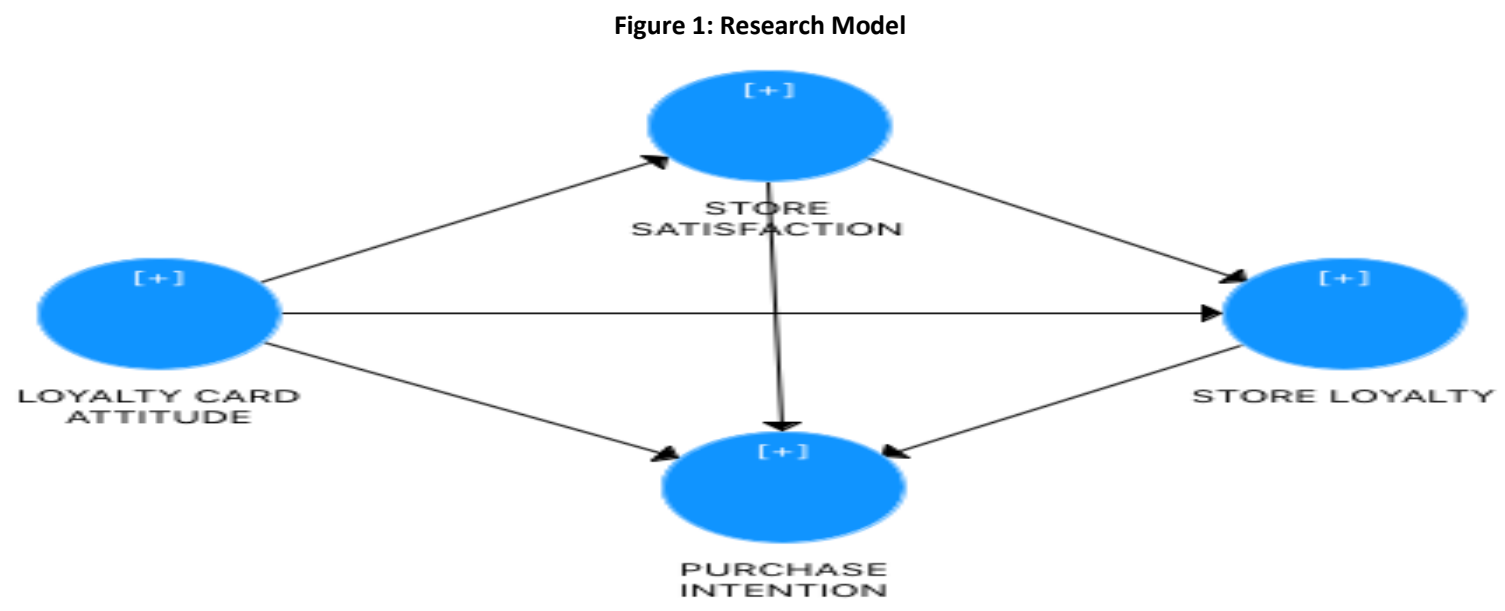

\section{DATA AND METHODOLOGY}

The aim of the research is to examine the effects of loyalty card programs on purchasing behavior of consumers in the cosmetics industry. The focus of the research is on four scales, Loyalty Card Attitude (LCA), Store Satisfaction (SS), Store Loyalty (SL) and Purchase Intention (PI). The study aims to understand which of these constructs influence the purchase intention of consumers for two cosmetics retailers, namely Gratis and Sephora. The two retailers are especially selected because they apply different loyalty card programs. While Sephora offers consumers to earn points from their each purchase and spend the accumulated points whenever they want, Gratis offers discounts on certain products at certain times of the year.

The vast majority of the scales in the questionnaire were taken from previously written academic articles. LCA, SS and SL are adapted from Bridson et. al. (2008) and PI is adapted from Macintosh \& Lockshin (1997)

The universe of the research is the consumers who use loyalty card of the selected cosmetic retailers in istanbul. A total of 200 respondents were used for the study. Most of these respondents were reached via social media and acquaintances of the researchers, thus convenience sampling method was used due to time and budget considerations. The majority of the sample is comprised of males (72\%), aged between $15-25(81 \%)$, university graduates (84\%), single (82\%) and having monthly household income above $5000 \mathrm{TL}(66 \%)$.

Table 1: Demographic Characteristics 


\begin{tabular}{|c|c|c|c|c|c|c|c|}
\hline \multicolumn{2}{|c|}{ DEMOGRAPHIC FEATURES } & \multirow{2}{*}{$\begin{array}{c}\text { FREQUENCY } \\
57 \\
\end{array}$} & \multirow{2}{*}{$\begin{array}{c}\text { PERCENT } \\
29 \\
\end{array}$} & \multicolumn{2}{|c|}{ DEMOGRAPHIC FEATURES } & \multirow{2}{*}{$\begin{array}{c}\text { FREQUENCY } \\
1\end{array}$} & \multirow{2}{*}{$\begin{array}{c}\text { PERCENT } \\
1\end{array}$} \\
\hline & Female & & & \multirow{4}{*}{ Education } & Primary School & & \\
\hline Gender & Male & 143 & 72 & & High School & 4 & 2 \\
\hline \multirow{3}{*}{ Age } & $15-25$ & 161 & 81 & & University & 168 & 84 \\
\hline & $26-35$ & 30 & 15 & & Master/Doctorate & 27 & 14 \\
\hline & $36-60$ & 9 & 5 & \multirow{7}{*}{ Occupation } & Self-Employment & 2 & 1 \\
\hline \multirow{2}{*}{ Marital Status } & Married & 36 & 18 & & Housewife & 6 & 3 \\
\hline & Single & 164 & 82 & & Worker & 2 & 1 \\
\hline \multirow{4}{*}{ Household Income } & $<1500$ & 19 & 10 & & Officer & 9 & 5 \\
\hline & $1501-5000$ & 1 & 26 & & Private Sector & 35 & 18 \\
\hline & $5001-10000$ & 59 & 30 & & Student & 138 & 69 \\
\hline & $>10000$ & 71 & 36 & & Unemployed & 8 & 4 \\
\hline
\end{tabular}

\section{FINDINGS AND DISCUSSION}

The assessment of the measurement model resulted in poor reliability and validity indicators for LCA. After the deletion of three items which had outer loadings lower than 0.5, Cronbach's Alpha (CA), Composite Reliability (CR) and Average Variance Extracted (AVE) increased. Resulting values of CA, CR and AVE are above the threshold levels of $0.7,0.8$ and 0.5 respectively for all constructs, indicating that the constructs have internal reliability and convergent validity. Additionally, discriminant validity is assured with Fornell Larcker criterion (Fornell \& Larcker, 1981). The model has good fit as the SRMR value is 0.077 , below the threshold level of 0.80 .

The structural model is assessed as the next step. LCA, SS and SL are found to affect the variation in PI by $0.69 \%$ (i.e. $R^{2}=0.69$ ). Afterwards, the $f^{2}$ effect size is examined to evaluate the influence of the three constructs on PI. As the findings indicate, the effect size of SL on PI is a medium effect size $\left(f^{2}=0.175\right)$, whereas LCA $\left(f^{2}=0.05\right)$ and SS $\left(f^{2}=0.01\right)$ exert low effect on PI.

To test the hypotheses and evaluate the path coefficients, Multi Group Analysis (MGA) and bootstrapping technique was used with 5000 sub-samples. The results of MGA are displayed in Table 2. As can be observed, hypothesized relationships are mostly accepted for Gratis. Among the six hypotheses, five of them are accepted for Gratis and only two of them are accepted for Sephora. More specifically, LCA and SL create PI for Gratis, but none of the constructs create PI for Sephora. For both of the cosmetics retailers, LCA has a significant positive influence on SS and SL, and this influence is higher for Sephora. However, SS exert a positive impact on SL only for Gratis.

Previous research has demonstrated that loyalty card programs would yield store satisfaction (Bridson et. al.,2008), store loyalty (Noordhoff et. al., 2004; Demoulin and Zidda, 2008) and purchase intention (Taylor and Neslin, 2005; Liu, 2007; Leenheer et al., 2007). However, this study found that depending on the type of loyalty card programs, the expected results could differ. Consistently, store satisfaction and store loyalty may not always result in purchase intention as it may depend on several other contingencies.

Table 2: Path Coefficients and PLS-MGA Results

\begin{tabular}{|c|c|c|c|c|c|c|c|}
\hline & \multicolumn{3}{|c|}{ Path Coefficients } & \multirow{2}{*}{$\begin{array}{c}\text { Path Coefficients- } \\
\text { diff (Gratis- } \\
\text { Sephora) }\end{array}$} & \multirow{2}{*}{$\begin{array}{c}\text { p-value } \\
\text { (Gratis vs. } \\
\text { Sephora) }\end{array}$} & \multicolumn{2}{|c|}{ Hypotheses } \\
\hline & Original & Gratis & Sephora & & & Gratis & Sephora \\
\hline LCA $\rightarrow$ PI & $0.228^{*}$ & $0.242 *$ & 0.354 & 0.112 & 0.708 & Accepted & Rejected \\
\hline LCA $\rightarrow$ SS & $0.772^{*}$ & $0.601 *$ & 0.876* & 0.275 & 0.001 & Accepted & Accepted \\
\hline $\mathrm{LCA} \rightarrow \mathrm{SL}$ & $0.356^{*}$ & $0.310^{*}$ & $0.737^{*}$ & 0.427 & 0.003 & Accepted & Accepted \\
\hline SS $\rightarrow$ PI & 0.114 & 0.152 & 0.026 & 0.126 & 0.469 & Rejected & Rejected \\
\hline$S S \rightarrow S L$ & $0.594 *$ & $0.590 *$ & 0.235 & 0.355 & 0.012 & Accepted & Rejected \\
\hline $\mathrm{SL} \rightarrow \mathrm{PI}$ & $0.530 *$ & $0.399 *$ & 0.559 & 0.160 & 0.536 & Accepted & Rejected \\
\hline
\end{tabular}

\section{CONCLUSION}

This study has found that depending on the type of loyalty card programs, their impact on the retailers' loyalty and purchase intention may differ. In this case, a loyalty card program that offers discounts (Gratis) instead of allowing consumers to spend the collected points of each purchase (Sephora) has created more purchase intention. On the other hand, loyalty card program of Sephora resulted in more store satisfaction and store loyalty than did Gratis. Therefore, cosmetics retailers are highly suggested to design loyalty programs depending on their expected return from the program, i.e. store satisfaction, store loyalty or purchase intention.

To the knowledge of the authors, this is the first attempt to examine the impact of loyalty card programs in the cosmetics industry. Future studies should focus on developing more research on the effect of different loyalty programs, as well as developing cross-cultural studies with larger samples.

\section{REFERENCES}

Cronin, J. J. \& Taylor, S. A. (1992). Measuring Service Quality: A Reexamination and Extension. Journal of Marketing, 56 (3), 55-68. 
Demoulin N. T. M. \& Zidda, P. (2008). On the Impact of Loyalty Cards on Store Loyalty: Does the Customers' Satisfaction with the Reward Scheme Matter? Journal of Retailing and Consumer Services, 15(5), 386-398.

Homburg, C. \& Giering, A. (2001). Personal Characteristics as Moderators of the Relationship between Customer Satisfaction and LoyaltyAn Empirical Analysis. Psychology and Marketing, 18 (1), 43-66.

Leenheer, J., van Heerde, H. J., Bijmolt, T. H. A. \& Smidts, A. (2007). Do Loyalty Programs Really Enhance Behavioral Loyalty? An Empirical Analysis Accounting for Self-Selected Members. International Journal of Research in Marketing, 24, 31-47.

Liu, Y. (2007). The Long-Term Impact of Loyalty Programs. Journal of Marketing, 71, 19-35.

Macintosh G. \& Lockshin, L. S. (1997). Retail Relationships and Store Loyalty: A Multi-level Perspective. International Journal of Research in Marketing, 14, 487-497.

Noordhoff, C., Pauwels P. \& Schröder, G. O. (2004). The Effect of Customer Card Programs A Comparative Study in Singapore and the Netherlands. International Journal of Service Industry Management, 15(4), 351-364.

Sharp, B. \& Sharp, A. (1997). Loyalty Programs and Their Impact on Repeat-Purchase Loyalty Patterns. International Journal of Research in Marketing, 14(5), 473-486.

Taylor, G. A. \& Neslin, S. A. (2005). The Current and Future Sales Impact of a Retail Frequency Reward Program. Journal of Retailing, 81(4), 293-305.

Zilliani, C. \& Bellini, S. (2004). From Loyalty Cards to Micro-marketing Strategies: Where is Europe's Retail Industry Heading? Measurement and Analysis for Marketing, 3(12), 281-290. 